Tersedia daring di:

\title{
Analysis of Procake Cake Shop Business Development Strategy
}

\author{
Hanief Rizqi Rahmatullah ${ }^{1}$, Woro Priatini ${ }^{1}$, Mandradhitya Kusuma $\mathbf{P}^{2}$ \\ ${ }^{1}$ Indonesia University of Education, Jl. Dr. Setiabudhi No. 229, Bandung 40154, Indonesia \\ ${ }^{2}$ NHI Tourism Academy, Jl. Raya Lembang KM 12.8, Kabupaten Bandung Barat 40391, \\ Indonesia \\ *Corresponding Author.E-mail: Hanifrizqir@gmail.com (Hanief Rizqi Rahmatullah)
}

\begin{abstract}
The changing time situation can increase business opportunities or threats for the company. One effort to find out the right strategy for the company is a SWOT analysis. There is an analysis of the internal environment, namely strengths and weaknesses, an analysis of the external environment, namely opportunities and threats. Thus, it is expected to be prepared in accordance with the predetermined business plan formulation. This research focuses on the question of how the company's position in the internal and external environment and what marketing strategies are applied to the Procake Shop based on SWOT analysis. The form of this research is a descriptive method with a quantitative approach. Data analysis techniques used in this study are using IFAS Matrix, EFAS Matrix, IE Matrix, SWOT Matrix and QSPM Matrix. IFAS and EFAS matrix analysis results are known that the internal factors with the highest score are product quality and prices, while for external factors is the bakery business trend. Based on the results of the IE matrix, Procake Cake Shop located in cell II is Growth. The position shows that the strategy used by the company is to expand the company by building in other locations, and improving the types of products and services. Based on the results of the Procake Cake SWOT quadrant position is in quadrant I, which supports an aggressive strategy that shows that the company has opportunities and strengths that can take advantage of existing opportunities. Therefore the authors recommend five alternative strategies for developing a Procake Cake Shop business based on an analysis of the SWOT matrix. Through QSPM data processing, it can be seen that alternative strategies are the main priority to be implemented at Procake Cake Shop is to expand the product sales network through consignment or joint ventures in winning the potential of the bakery business with a value of 6.11 Stas.
\end{abstract}

Keywords: Development; Bakery; SWOT

First Received: April $2019 \quad$ Revised: Mei $2019 \quad$ Accepted: Juni 2019

Final Proof Received: December 2019

Published: December 2019 


\section{Introduction}

Indonesia is one of the countries with enormous cultural diversity. Each region in Indonesia has its own characteristics and uniqueness. In addition, Indonesia also has a very beautiful and enchanting natural charm, often even becoming a recommendation for tourist destinations for foreign and local tourists. Both of them are Indonesia's potential to progress and develop, especially in the tourism sector. Based on these facts, the Indonesian government is aggressively developing this tourism sector so that it becomes one of the sectors that will benefit and prosper the country and the people of Indonesia.

The culinary business has become one of the business potentials that can bring benefits to all parties in the tourism sector in West Bandung Regency, including culinary business, tourists, and the government. For culinary business, this potential can be a chance to find a lot of profit. For tourists, culinary business can be one of the factors that will ruin and satisfy the tour they are doing, or as something they will bring home for the family or relatives from which they come. For the government, culinary business can be used as an attraction to bring more tourists to West Bandung Regency. In addition, the culinary business can be used as one of the factors of economic growth.

The culinary business has become one of the very promising businesses for a new culinary business in West Bandung Regency. Therefore culinary business people in West Bandung Regency both old and new will compete closely to attract customers to buy the products they sell.

One of the culinary business is pastry / bakery or known as bakery. This bakery business has great potential for tourists who come to West Bandung regency because this product can be used as a substitute food or can also be a souvenir that can be brought home by tourists for family or relatives when returning to their original place. Lots of bakery brands in West Bandung Regency which are already widely known by tourists are Kartika Sari, Mayasari, Bolu Susu Lembang, Makuta, Princess Cake and many more.

The author is interested in choosing Procake as the object of research because Procake is a bakery that intensively tries to develop its business by selling its products at affordable prices but quality remains a top priority. This Procake Cake Shop makes a strategy by marketing its products in cake shops that have many branches so that the products of this Procake are better known to many people around the District of West Bandung, Cimahi and the City of Bandung.

The culinary business has become one of the business potentials that can bring benefits to all parties in the tourism sector in West Bandung Regency, including culinary business, tourists, and the government. For culinary business, this potential can be a chance to find a lot of profit. For tourists, culinary business can be one of the factors that will ruin and satisfy the tour they are doing, or as something they will bring home for the family or relatives from which they come. For the government, culinary business can be used as an attraction to bring more tourists to West Bandung Regency. In addition, the culinary business can be used as one of the factors of economic growth.

Based on the data above, culinary business is one of the most promising businesses for new culinary entrepreneurs in West Bandung Regency. Therefore culinary business people in West Bandung Regency both old and new will compete closely to attract customers to buy the products they sell.

One of the culinary business is pastry / bakery or known as bakery. This bakery business has great potential for tourists who come to West Bandung Regency because this product can be used as an alternative food or can also be a souvenir that can be brought home by tourists for family or relatives when returning to their original place. Lots of bread brands in West Bandung Regency are already well known by tourists, 
including Kartika Sari, Mayasari, Bolu Susu Lembang, Makuta, Kue Putri and many more.

One of the bread brands that has been established since 2006 in West Bandung is Procake. Procake is visited by buyers because the price is quite affordable but the quality can be compared with some well-known bakeries in West Bandung Regency and in the City of Bandung.

The author is interested in choosing Procake as the object of research because Procake is a bakery that intensively tries to develop its business by selling its products at affordable prices but quality remains a top priority. This Procake Cake Shop makes a strategy by marketing its products in cake shops that have many branches so that the products of this Procake are better known to many people around the District of West Bandung, Cimahi and the City of Bandung.

Procake currently has two outlets, both of which have strategic locations. The first outlet to be a central outlet is located on Jl. Lieutenant Colonel GA Manulang No. 301 and the second outlet is located on $\mathrm{Jl}$. Purwakarta No. 438. strategic location bearing in mind that the place is right in front of the TNI education center and is also a densely populated residential area surrounded by places where community centers of activity such as schools, TNI education centers, sports facilities and other business centers. This strategic location has resulted in many other competitors establishing similar businesses, which of course could threaten Procake's existence. For example there are similar business outlets not far from Procake outlets, and many other competitors that are no less unique and tasty than Procake.

Products provided by Procake every day are always "fresh from the oven" or in other words, cake products sold on that day are new products made on the same day. In addition they also have products that are trending at that time such as makuta, sponge milk cake and princess cake.

Procake has 10 types of cakes and various types of bread that are produced every day except Sundays due to holidays. One type of cake variant which is a best seller and a mainstay of a Procake cake shop is Banana Cake. Not only Banana Cake, Butter Cake also like Bolu Sticky Rice, Brownies steamed and grilled, Marble Cake and other types of bread that are no less tasty and much in demand.

Based on these things, it can be seen that Procake outlets have good potential to become one of the bakeries that can be chosen by the community, especially in West Bandung and Cimahi Regencies. Considering that the Procake pastry shop has a strategic location, there are many product variants, and the quality of its products is not inferior to other brands, but the price of its products is still affordable for the people of West Bandung and Cimahi.

The number of sales of Procake Cake Shop products has declined in the last 2 years. In 2017 Procake Shop received 65850 temporary purchases, in 2018 Procake Shop received 44220 purchases, which means that Procake Shop has decreased by 21,630 or $33.15 \%$. Decreasing the number of orders certainly has an impact on the decrease in the amount of turnover obtained by Procake Cake Shop

In 2017 Procake Shop receives as much as Rp. 3,729,053,500 while, in 2018 Procake Shop received as much as Rp. 2,713.156230 which means, Procake Cake Shop experienced a turnover of Rp. $1,015,897,270$ or $27.25 \%$.

Therefore, there are several things that are thought to cause a decrease in profits due to competition in the bakery. West Bandung is tight. Therefore, strategic planning is needed to increase sales intensity so that business targets (increased profits) can survive in the fierce competition of Bakery in this Regency. West Bandung and can face problems that arise both from the internal and external environment of the Procake Padalarang cake shop.

Determine the business strategy, it is necessary to do an analysis that can produce 
a strategy that suits business needs. in this study the authors will use various methods of corporate environmental analysis as a tool to determine business strategies that are in accordance with the environmental conditions of the Procake Padalarang cake shop. Therefore this research is entitled "Business Development Strategies at Procake Cake Shop in Padalarang".

\section{Literature Review}

\subsection{Tourism}

According to (Sulastiyono, 2008) tourism is a process that can make goods and services have added value and make it a unified product, both tangible and intangible.

Based on the theory it can be concluded that tourism is a travel process that creates an increase in the value of goods and services, this occurs as a result of the demand for these goods and services caused by the large number of people who carry out tourism activities that travel to these places.

\subsection{Culinary Tourism}

According to the KBBI Culinary tourism comes from two words; tourism and culinary. Tourism is traveling together to expand knowledge, insight, etc., while culinary is cuisine or food. So culinary tourism is traveling together to broaden your knowledge about food.

Culinary tourism is as a process of searching for unique culinary experiences and is always remembered with a variety of types, which are often enjoyed in every trip, but we can also become culinary tourists at home, (Dafila, Kun, \& Dhanik, 2016).

Culinary tourism can generally be defined as visits to food and beverage producers, food and beverage festivals, restaurants and specific locations for food and beverage tasting and / or enjoying / learning their production. Thus drinks and special attributes of regional specialty drinks become the basis and the main driving factor in tourist trips (C. Michael
Hall, Liz Sharples \& Cambourne, 2003).

\subsection{Bakery}

In English, bakery means bakery and cake shop. According to Rogak (2016: 3) in the thesis (Zuwita, 2012) the bakery and bakery business is a business that provides fresh baked bread, cakes, snacks, and snacks for customers and / or wholesale buyers.

According to (Faridah, 2008) bakery is part of a patisserie consisting of bread, cake, pastry and cookies. Bakery products are made using a variety of basic ingredients, such as flour, fat, sugar, eggs, salt and liquid (can be milk or water).

So it can be interpreted that bakery is a business that sells a variety of breads, cakes, pastries, and cookies. Made with basic ingredients (such as flour, fat, sugar, eggs, salt, and liquid) and served fresh or fresh to customers.

\subsection{Strategic Management}

According to (Rangkuti, 2015b) the main objective of strategic planning is so that the company can see objectively the internal conditions, so that the company can anticipate changes in the external environment. Strategic planning is important to obtain competitive advantage and have a product that is in accordance with the wishes of consumers with optimal support from existing resources.

So, it can be concluded that the purpose of strategic planning is to obtain a competitive advantage so that the company has a better performance than competitors in similar markets. To achieve this competitive advantage, companies must understand internal conditions in order to anticipate external companies.

Based on the theory above, it can be concluded that in general there are stages in the strategic management process, namely the first is the identification of the company (vision, mission, and strategies used today), 
the second is the analysis of the company's internal and external environment, third, the formulation of strategies, the fourth is implementation strategy, and the last is evaluation strategy.

\subsection{SWOT Analysis}

SWOT analysis is a strategic planning method used to evaluate strengths, weaknesses, opportunities and threats in a project or business. The four factors that form the acronym SWOT (strengths, weaknesses, opportunities, and threats) (David, 2004). This process involves setting specific goals from business or project speculation and identifying internal and external factors that support and which do not achieve these goals.

SWOT analysis can be applied by analyzing and sorting out various things that affect the four factors, then applying it in the SWOT matrix image, where the application is how strengths are able to take advantage of the opportunities available, how to overcome weaknesses (how to overcome weaknesses) weaknesses that prevent the advantages of opportunities that exist, then how strengths are able to deal with existing threats, and finally how to overcome weaknesses that are able to make threats real or create a new threat (David, 2004).

\subsection{External Strategy Factor Matrix (EFAS)}

According to Rangkuti (2015) after the internal strategic factors of a company were identified an IFAS table was prepared to formulate these internal strategic factors within the framework of the company's Strength and Weakness. The stages are as follows:

a. Determine the factors that are the strengths and weaknesses of the company in column 1.

b. Give the weight of each of these factors a scale ranging from 1.0 (most important) to 0.0 (not important), based on the influence of these factors on the company's strategic position. (All of these weights cannot exceed the total score of 1.00.)

c. Calculate the rating (in column 3) for each factor by giving a scale ranging from 4 (outstanding) to 1 (poor), based on the influence of these factors on the condition of the company concerned. Positive variables (all variables included in the strength category) are given values ranging from +1 to +4 (very good) by comparing them with industry averages or with major competitors. While negative variables, the opposite. For example, if a company's weakness is huge compared to the industry average, the value is 1 , whereas if the company's weakness is below the industry average its value is 4.

d. Multiply the weights in column 2 by rating in column 3 , to get a weighting factor for each factor whose value varies from 4.0 (outstanding) to 1.0 (poor).

e. Use column 5 to provide comments or notes why certain factors were selected, and how the weighting balance is calculated.

f. Add up the weighting score for the company concerned. This total value shows how a particular company reacts to its internal strategic factors.

\subsection{SWOT Matrix}

\subsubsection{Strenght}

Strength is a resource / capability that is controlled or available to a company that makes the company relatively superior compared to its competitors in meeting the needs of the customers it serves. Strength comes from the resources and competencies available to the company.

\subsubsection{Weakness}

Weakness is a limitation / deficiency in one or more resources / capabilities of a company relative to its competitors, which is an obstacle in meeting customer needs 
effectively.

\subsubsection{Opportunity}

Opportunities are the main favorable situation in a company's environment. The main tendency is one source of opportunity.

\subsubsection{Threat}

Threats are the main unfavorable situations in a company's environment. Threats are the main obstacle for the company in achieving the desired position.

\section{Materials and Methods}

The purpose of this research is to find a business development strategy in Procake Padalarang Cake Shop located on Lt. Col. GA Manulang street, No. 301 Purabaya Padalarang, this study will focus on business development strategies using company environmental analysis by analyzing internal factors including business strengths and weaknesses, and external factors that become opportunities and threats of the business. The results of the analysis can be used to find out what strategies are suitable to be applied in the business.

The method used by the writer in this research is descriptive quantitative method. The purpose of this descriptive study is to solve systematic and factual problems regarding the facts and characteristics of the population. A quantitative approach will be used to get a rating from Procake Shop employees and Procake Shop customers to the internal and external factors of the Procake Shop SWOT analysis.

This study is intended to describe the actual situation based on facts or events and existing data, then the data is processed, analyzed and further processed on the basis of theories that are studied and used as discussion material so that ultimately it produces a conclusion that can be used as a basis for providing the best advice for places and managers that are subject to research.

The population in this study are Procake Cake Shop Owners, Procake Cake Shop employees and Procake Cake Shop customers. The target of Procake Cake Shop consumers who are the subjects in this study are consumers who buy Procake Cake Shop products.

Author using formulas Isac and Michael in determining the sample to consumers Cake Shop Procake with data on the number of consumers in 2018 was 44220. Based on the description and Michael Isac table is then used as a sample size of respondents in this study population of 44 220 visits from people in 2018 and an error rate of $10 \%$ is as many as 270 people, with the intended respondent namely Procake Cake Shop consumers.

\section{Results and Discussion}

\subsection{Company Overview}

The object of research is an important part of a study, which is the focus of the research. The object of the study describes what or who is the object of the study. You can also add other things if necessary. The object of research in this study is how to apply good strategies for the development of the Procake Cake Shop business.

The research subject was conducted at Procake Cake Shop located at Jl. Letkol GA Manulang No.301 RT 01 RW 03 Purabaya Kel. Jayamekar Kec. Padalarang Regency. West Bandung. This bakery has been established since 2006, this cake shop is one of the most crowded bakeries visited by buyers because the price is quite affordable but quality can be compared with some of the top brand bakeries in West Bandung Regency and in the City of Bandung.

The founder of this Bakery is Mrs. Euis Dartika, starting from her own money, this Bakery only serves orders, over time this bakery began to develop to be able to set up some cake shops and also a pretty good place of production. The company opened a branch in 2012 in the Cikalong Wetan area.

The current owner of Procake Cake Shop, Mrs. Euis Dartika, allows the author to conduct research there. Researchers chose Procake Cake Shop as a research object because Procake Cake Shop is a bakery that can compete with other bakery merchants in 
Kab. West Bandung, but the number of revenues and sales of Procake Cake Shop has decreased in the last 2 years.

The Procake Cake Shop has interesting product variants including:

\section{a. Black Forest}

This cake is made from chocolate sponge coated with fresh cream, chocolate shavings and cherries soaked in Kirschwasser, clear cherry schnapps typical of the Schwarzwälder region. The Procake Cake Shop has several forms for this black forest cake including squares, rectangles and rounded shapes.

b. Tart

A tart is a baked food, the basic ingredients of a pastry cake and filled with something sweet or savory, but the top of this food is not covered or coated with pastry. The contents of modern tarts are usually fruit-based, sometimes with custard. Whereas a tartlet is a small tart.

\section{c. Brownies}

Brownies are flour, butter, sugar, eggs, melted chocolate, and almonds. This is a sure thing that the basic recipe for brownies has not changed since hundreds of years ago. At this time brownies have undergone many modifications with a variety of additional flavors such as cheese brownies, banana brownies, blueberries, strawberries, beans, coffee, and many other variations of brownies. Likewise with the way the manufacturing process is not only baked, but can also with the steaming process known as steamed brownies. The Procake Cake Shop has 2 variants of brownies namely roasted brownies and steamed brownies.

\section{d. Banana Cake}

Banana sponge is one of the most popular sponge recipes. By using bananas, you can already produce delicious sponge cake. Fragrant banana sponge cake with soft cake texture.

e. Marble Cake
Marble cake or commonly called a marble cake is a cake that is commonly found as afternoon tea, a classic friend, a loyal colleague of tea or coffee.

\section{f. Cassava Cake}

Cassava cake or commonly known as bolu cassava in Sundanese peyeum.

\section{g. Glutinous Cake}

Sticky rice cake is made from black sticky rice, this one is soft-textured and will look like brown sponge because of the color produced from the sticky rice sponge.

\section{h. Cookies}

Pastries are cakes that have a hard, crunchy, and long-lasting texture. The water content is low because pastries are made by oven or baking. The ingredients for making pastries include rice flour, glutinous rice flour, or tapioca flour, butter, sugar, and eggs.

\subsection{Recapitulation of Company's Internal} and External Environmental Analysis

After conducting research and data collection through the distribution of questionnaires, interviews and further documentation studies will be carried out a recapitulation of internal and external factors in the form of strengths and weaknesses as well as opportunities and threats of Procake Cake Shop. The recapitulation is as follows:

a. Factors that become the internal strength of Procake Shop:

1) Number of employees owned by Procake Cake Shop

2) Product quality

3) Affordable product prices

4) Strategic outlet location

5) Work ability and employee loyalty

6) Segmentation and target market

7) Establish work shifts for employees

8) Performance and support from superiors

9) Comfortable work environment 
b. Factors that become the internal weaknesses of Procake Shop:

1) Hospitality and employee performance are less than optimal

2) Inconsistent product packaging

3) Production equipment that is rarely renewed

4) Employee facilities that do not meet the standards

5) Financial management that is not going well

6) Promotions made have not been maximized

7) Selection of suppliers that are less selective and procurement of raw materials

8) Sanitation and hygiene do not have standards

9) Irregular operating hours

10) Production sites that do not meet standards

c. Factors that constitute an external opportunity for Procake Shop:

1) The company fulfills the licensing and certification of establishing a bakery business

2) The company has halal certification from MUI and BPOM certification

3) Increased bakery business trends

4) Bakery business opportunity in the era of technology

d. Factors that pose external threats to Procake Shop

1) The number of competitors is increasing every year.

2) The business competition of similar businesses is saturated.

3) The rise of artists / celebrities who founded the bakery business.

\subsection{IFAS Matrix Analysis}

The Internal Strategic Factors Analysis Summary (IFAS) table has been prepared to formulate these internal strategic factors within the company's Strength and Weakness framework. Here is the IFAS Cake Shop Procake matrix analysis.

Table 1. IFAS Matrix Analysis of Procake Cake Shop

\begin{tabular}{|c|c|c|c|c|}
\hline Internal Strategy Factors & Weight & Rating & $\begin{array}{c}\text { Weight } \\
\text { X } \\
\text { Rating } \\
\end{array}$ & Comment \\
\hline \multicolumn{5}{|l|}{ Strength: } \\
\hline 1. Product quality and price. & .18 & 4 & 0.72 & \multirow{7}{*}{$\begin{array}{l}\text { Company's } \\
\text { strength to } \\
\text { compete with } \\
\text { other similar } \\
\text { industry. }\end{array}$} \\
\hline 2. Outlet location & & & & \\
\hline $\begin{array}{l}\text { 3. Bosses and work } \\
\text { environment }\end{array}$ & 0.14 & 3 & 0.42 & \\
\hline 4. Establishing work shifts & 0.09 & 3 & 0.27 & \\
\hline $\begin{array}{l}\text { 5. Number, ability and loyalty } \\
\text { of employees }\end{array}$ & 0.08 & 2 & .16 & \\
\hline $\begin{array}{l}\text { 6. Segmentation and target } \\
\text { market }\end{array}$ & .10 & 1 & .10 & \\
\hline & .11 & 1 & .11 & \\
\hline \multicolumn{5}{|l|}{ Weakness: } \\
\hline 1. Product packaging & 0.08 & 4 & 0.32 & \multirow{7}{*}{$\begin{array}{l}\text { Below the average } \\
\text { comparison of } \\
\text { other similar } \\
\text { industries. }\end{array}$} \\
\hline $\begin{array}{l}\text { 2. Production equipment and } \\
\text { facilities }\end{array}$ & 0.06 & 3 & .18 & \\
\hline 3. Working hours of operation & & & & \\
\hline $\begin{array}{l}\text { 4. Supplier and procurement } \\
\text { of raw materials }\end{array}$ & 0.04 & 3 & 0.12 & \\
\hline 5. Hygiene and sanitation & 0.05 & 2 & .10 & \\
\hline \multirow{2}{*}{ 6. Financial management } & 0.04 & 1 & 0.04 & \\
\hline & 0.03 & 1 & 0.03 & \\
\hline
\end{tabular}


TOTAL $\mathbf{1 , 0 0}$ 2.57

Source : Data processing by author (2019)

Table 1 shows the calculation of the IFAS matrix obtaining a weighted average value of 2.57. According to Fredy Rangkuti (2015) if the IFAS matrix calculation is above 2.5 it means that the company's internal conditions are strong. Based on this Procake Cake Shop the internal factors are already strong.
After the external strategic factors of a company are identified, an EFAS (External Strategic Factors Analysis Summary) table is compiled to formulate these external strategic factors within the framework of the company's opportunities and threats. Following is the EFAS Cake Shop Procake matrix analysis:

\subsection{EFAS Matrix Analysis}

Table. 2 EFAS Matrix Analysis of Procake Cake Shop

\begin{tabular}{|c|c|c|c|c|}
\hline External Strategy Factors & Weight & Rating & $\begin{array}{l}\text { Weight } \\
\text { X } \\
\text { Rating }\end{array}$ & Comment \\
\hline \multicolumn{4}{|l|}{ Opportunities: } & \multirow{6}{*}{$\begin{array}{l}\text { Conditions that } \\
\text { can be utilized by } \\
\text { companies to } \\
\text { develop business. }\end{array}$} \\
\hline 1. Halal certification and BPOM & 0.14 & 3 & 0.42 & \\
\hline 2. Government licensing and & .16 & 3 & 0.48 & \\
\hline certification & .17 & 4 & 0.68 & \\
\hline 3. $\quad$ Bakery business trends & .13 & 2 & 0.26 & \\
\hline 4. Technological development & & & & \\
\hline \multicolumn{5}{|l|}{ Threats: } \\
\hline $\begin{array}{l}\text { 1. Increasing number of } \\
\text { competitors }\end{array}$ & 0.14 & 4 & 0.56 & \multirow{4}{*}{$\begin{array}{l}\text { Threats that must } \\
\text { be considered by } \\
\text { the company. }\end{array}$} \\
\hline $\begin{array}{l}\text { 2. Celebrities who founded bakery } \\
\text { businesses }\end{array}$ & .13 & 4 & 0.52 & \\
\hline 3. Saturated business competition & .13 & 2 & 0.26 & \\
\hline TOTAL & 1,00 & & 3.18 & \\
\hline
\end{tabular}

Table 2 shows the calculation of the EFAS matrix obtaining a weighted average value of 3.18. According to Fredy Rangkuti (2015) if the EFAS matrix calculation above 2.5 means that the company is able to take advantage of opportunities and overcome threats. Based on that Procake Cake Shop has been able to take advantage of opportunities and avoid threats that are external factors.

\subsection{IE Matrix}

Internal and external matrix consists of two dimensions, namely the total value of the IFAS matrix on the $Y$ axis of the total value of the EFAS matrix on the $\mathrm{X}$ axis there are three scores, namely a score of $1.0-1.99$ states that the internal position is weak, a score of $2.0-2.99$ is the average, and 3.0 4.0 is the strength that is set from right to left. The same way, for the $\mathrm{Y}$ axis the score is three too, namely a score of $1.0-1.99$ stating that the external position is low, a score of $2.0-2.99$ is an average and $3.0-4.0$ is high set from the bottom up. The calculation results of IFAS and EFAS Matrix Cake Shop analysis produce a value of 2.57 for the IFAS matrix and 3.18 for the EFAS matrix value so based on these results, the position of the Procake Cake Shop based on IE matrix analysis is as follows:

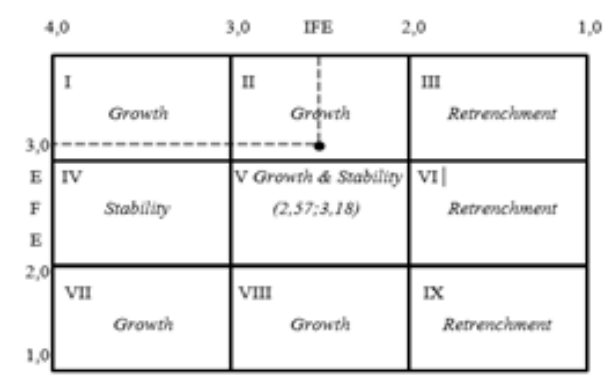

Source : Data processed (2019)

Figure 1. Results of Anaysis of Matrix IE Procake Cake Shop 
Figure 1 shows the results of IE matrix analysis Procake Cake Shop position is in cell II, namely Growth. According to Fredy Rangkuti (2015), if the position of the IE matrix analysis is in cell 2, a good growth strategy used is constentation through horizontal integrity.

According to Freddy Rangkuti (2015) growth strategy through horizontal integration is an activity to expand the company by building in other locations, and improving the types of products and services.

If, the company is in a very attractive industry (cell II), the aim is to increase sales and profits, by utilizing the benefits of economics scale both in production and marketing.

\subsection{Position of Quadrant SWOT}

The next step is determining the position of the SWOT quadrant for the Procake Cake Shop to determine what the potential strategy is. After the IFAS, EFAS and IE matrix analyzes, the following is the position of the Procake Cake Shop SWOT quadrant:

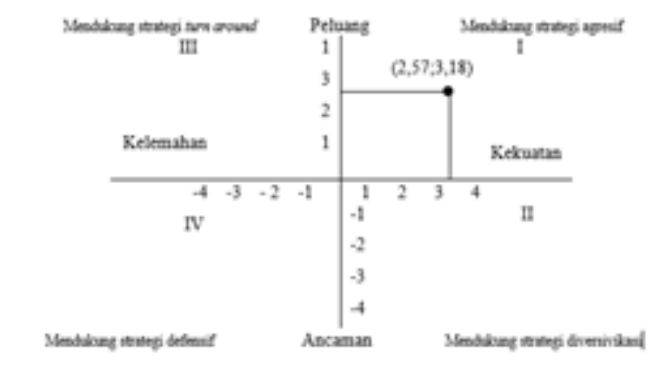

Source : Data processed (2019)

Figure 2. Position of Quadrant SWOT Procake Cake Shop

Figure 2 shows the position of the Procake Cake Shop SWOT quadrant is in quadrant I with coordinates $2.57 ; 3.18$ which supports an aggressive strategy. This quadrant shows a very favorable situation because the company has opportunities and strengths so that it can take advantage of existing opportunities. The strategy that must be applied to support this condition is an aggressive growth policy (Growth Oriented Strategy).

\subsection{SWOT Matrix}

The tool used to compile the company's strategic factors is the SWOT matrix. This matrix can clearly illustrate how external opportunities and threats faced by the company can be adjusted to the strengths and weaknesses they have. This matrix can produce four sets of possible strategic alternatives that can be done by Procake Cake Shop. The following is the Procake Cake Shop SWOT matrix analysis:

Table. 3 Matrix SWOT Procake Cake Shop

\begin{tabular}{|c|c|c|}
\hline IFAS & Strengths & Weaknesses \\
\hline & Product quality and price & Product packaging \\
\hline & Outlet location & Production equipment \\
\hline & Bosses and work & and facilities \\
\hline & environment & 3. Working hours of \\
\hline & 4. Establishing work shifts & operation \\
\hline & $\begin{array}{l}\text { 5. The number of abilities and } \\
\text { employee loyalty }\end{array}$ & $\begin{array}{l}\text { 4. Supplier and } \\
\text { procurement of raw materials }\end{array}$ \\
\hline & 6. Segmentation and target & 5. Hygiene and sanitation \\
\hline EFAS & market & Financial management \\
\hline Opportunies & & \\
\hline 1. Halal certification and & 1. Expanding the product sales & 1. Standardize in all lines of \\
\hline $\begin{array}{l}2 . \quad \text { Government licensing and } \\
\text { certification. }\end{array}$ & $\begin{array}{l}\text { or joint ventures in winning the } \\
\text { potential of the bakery business }\end{array}$ & $\begin{array}{l}\text { renew production equipment to } \\
\text { maximize the company's }\end{array}$ \\
\hline
\end{tabular}




\begin{tabular}{|c|c|c|}
\hline $\begin{array}{l}3 . \quad \text { The trend of bakery } \\
\text { business in Bandung } \\
4 \text {. Technological } \\
\text { development }\end{array}$ & $\begin{array}{l}\text { (S2, S5, S6, O1, O3, ) } \\
2 . \quad \text { Take advantage of } \\
\text { technological developments in } \\
\text { maximizing marketing to increase } \\
\text { sales volume. } \\
\text { S1, S3, S6, O3, O4) }\end{array}$ & $\begin{array}{c}\text { operational quality. } \\
\mathrm{W} 1, \mathrm{~W} 2, \mathrm{~W} 6, \mathrm{O} 1, \mathrm{O} 2, \mathrm{O} 4)\end{array}$ \\
\hline \multicolumn{3}{|c|}{ 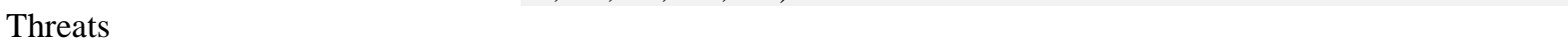 } \\
\hline $\begin{array}{l}\text { 1. The number of } \\
\text { competitors is steadily increasing } \\
2 . \quad \text { Celebrities who founded } \\
\text { bakery businesses. } \\
3 \text {. Saturated business } \\
\text { competition }\end{array}$ & $\begin{array}{l}\text { 1. Adding types of products } \\
\text { and services in the face of } \\
\text { increasingly intense competition in } \\
\text { the bakery industry that continues } \\
\text { to increase. ( } \mathrm{S} 1, \mathrm{~S} 3, \mathrm{~S} 5, \mathrm{~T} 1, \mathrm{~T} 2 \text {, } \\
\mathrm{T} 3 \text { ) }\end{array}$ & $\begin{array}{l}\text { 1. Maximizing the quality } \\
\text { of human resources and } \\
\text { production operations by } \\
\text { conducting training around } \\
\text { company SOPs. } \\
\text { (W1,W2,W3,W4,W5,T1,T2,T3) }\end{array}$ \\
\hline
\end{tabular}

Table 4 shows that there were 5 alternative strategies for Procake Shop based on the results of the SWOT matrix analysis. Here is an explanation and explanation of 5 alternative Procake Shop strategy:

\section{a. SO Strategy}

This strategy is based on the company's way of thinking, namely by using all the company's strengths to take advantage of Procake Cake Shop opportunities.

1) Expanding the product sales network through consignment or joint ventures in winning the potential of the bakery business.The Procake Cake Shop Company expanded its product sales network by collaborating with other similar companies, such as leaving its products to outlets selling the same type of product lines, this effort was carried out to expand the sales market.

2) Take advantage of technological developments in maximizing marketing to increase sales volume. Technological developments can be used as a company as an opportunity to maximize marketing to increase sales volume. Companies can take advantage of current food delivery service trends such as Go-food or grab food.

\section{b. ST Strategy}

This strategy was made using the strength of the Procake Cake Shop to avoid threats.
Adding types of products and services in the face of increasingly intense competition in the bakery industry that continues to increase.

Product innovation is an alternative strategy that can be done by the company in increasing competitiveness, by conducting quality product innovations, the Procake Cake Shop can have an attraction that is able to compete with similar companies.

\section{c. WO Strategy}

This strategy is applied based on the utilization of existing opportunities, by overcoming the weaknesses that are owned by Procake Cake Shop.

Standardize in all lines of the company's organization and renew production equipment to maximize the company's operational quality.

Standardization is carried out in the production operational lines, financial management, HR recruitment, marketing management and all information about company organizations in order to maximize company operations. The company also renewed facilities and technology to support the company's production activities.

\section{d. WT Strategy}

This strategy is implemented based on minimizing the existing weaknesses to overcome the threats that come.

Maximizing the quality of human resources and production operations by conducting training around company SOPs.

The company conducts training 
around company SOPs such as sanitation hygiene, establishes working hours and good work shifts to improve the quality of professional employees in production operations

\subsection{QSPM Matrix}

This stage is a technique that can objectively set alternative strategies prioritized as a QSPM technique that requires good intuitive judgment. QSPM uses input from IFAS SWOT matrix analysis and EFAS SWOT matrix analysis results. Based on the results of the SWOT analysis obtained 5 alternative strategies for the development of the Procake Cake Shop business. To determine the right alternative strategy as a priority, a QSPM analysis can be seen in the following table:

Table 4. Results of QSM Matrix Analysis of Procake Cake Shop

\begin{tabular}{|c|c|c|c|c|c|c|c|c|c|c|c|c|}
\hline \multirow{3}{*}{\multicolumn{2}{|c|}{ Main Factor }} & \multirow{3}{*}{ Weight } & \multicolumn{10}{|c|}{ Procake Cake Shop Business Development Strategy } \\
\hline & & & \multicolumn{2}{|c|}{ Strategy 1} & \multicolumn{2}{|c|}{ Strategy 2} & \multicolumn{2}{|c|}{ Strategy 3} & \multicolumn{2}{|c|}{ Strategy 4} & \multicolumn{2}{|c|}{ Strategy 5} \\
\hline & & & AS 1 & TAS1 & AS 2 & TAS2 & AS 3 & TAS3 & AS 4 & TAS4 & AS 5 & TAS5 \\
\hline \multicolumn{13}{|c|}{ Internal Strategic Factors Analysis Summary \& External Srategic Factors Analysis Summary } \\
\hline \multirow{6}{*}{ Strength } & S 1 & 0.18 & 4 & 0.72 & 3 & 0.54 & 2 & 0.36 & 2 & 0.36 & 2 & 0.36 \\
\hline & S 2 & 0.14 & 4 & 0.56 & 3 & 0.42 & 2 & 0.28 & 2 & 0.28 & 4 & 0.56 \\
\hline & S 3 & 0.09 & 3 & 0.27 & 4 & 0.36 & 3 & 0.27 & 3 & 0.27 & 3 & 0.27 \\
\hline & S 4 & 0.08 & 4 & 0.32 & 2 & 0.16 & 2 & 0.16 & 2 & 0.16 & 4 & 0.32 \\
\hline & S 5 & 0.10 & 4 & 0.40 & 3 & 0.30 & 4 & 0.40 & 3 & 0.30 & 1 & 0.10 \\
\hline & S 6 & 0.11 & 3 & 0.33 & 2 & 0.22 & 2 & 0.22 & 2 & 0.22 & 2 & 0.22 \\
\hline \multirow{5}{*}{ Weakness } & W 1 & 0.08 & 2 & 0.16 & 2 & 0.16 & 3 & 0.24 & 1 & 0.08 & 3 & 0.24 \\
\hline & W 2 & 0.06 & 2 & 0.12 & 1 & 0.06 & 2 & 0.12 & 1 & 0.06 & 3 & 0.18 \\
\hline & W 3 & 0.04 & 3 & 0.12 & 1 & 0.04 & 3 & 0.12 & 2 & 0.08 & 2 & 0.08 \\
\hline & W 4 & 0.05 & 2 & 0.10 & 2 & 0.10 & 2 & 0.10 & 1 & 0.05 & 4 & 0.20 \\
\hline & W 5 & 0.04 & 1 & 0.04 & 2 & 0.08 & 1 & 0.04 & 1 & 0.04 & 1 & 0.04 \\
\hline \multirow{4}{*}{ Oppurtunity } & W 6 & 0.03 & 2 & 0.06 & 1 & 0.03 & 1 & 0.03 & 1 & 0.03 & 2 & 0.06 \\
\hline & $\mathrm{O} 1$ & 0.17 & 4 & 0.68 & 3 & 0.51 & 1 & 0.17 & 1 & 0.17 & 2 & 0.34 \\
\hline & O 2 & 0.16 & 3 & 0.48 & 2 & 0.32 & 2 & 0.32 & 2 & 0.32 & 2 & 0.32 \\
\hline & O 3 & 0.14 & 4 & 0.56 & 3 & 0.42 & 2 & 0.28 & 3 & 0.42 & 3 & 0.42 \\
\hline \multirow{4}{*}{ Threat } & $\mathrm{O} 4$ & 0.13 & 4 & 0.52 & 2 & 0.26 & 3 & 0.39 & 4 & 0.52 & 2 & 0.26 \\
\hline & $\mathrm{T} 1$ & 0.14 & 2 & 0.28 & 3 & 0.42 & 2 & 0.28 & 3 & 0.42 & 3 & 0.42 \\
\hline & $\mathrm{T} 2$ & 0.13 & 2 & 0.26 & 1 & 0.13 & 3 & 0.39 & 2 & 0.26 & 2 & 0.26 \\
\hline & T 3 & 0.13 & 1 & 0.13 & 1 & 0.13 & 1 & 0.13 & 3 & 0.39 & 3 & 0.39 \\
\hline \multicolumn{3}{|c|}{ Total } & & 6.11 & & 4.66 & & 4.30 & & 4.43 & & 5.04 \\
\hline \multicolumn{3}{|c|}{ Priority Strategies } & \multicolumn{2}{|r|}{ I } & \multicolumn{2}{|c|}{ III } & \multicolumn{2}{|c|}{$\mathrm{V}$} & \multicolumn{2}{|c|}{ IV } & \multicolumn{2}{|c|}{ II } \\
\hline
\end{tabular}

Table 4 shows that the results of the QSPM matrix calculation results can be identified 5 priority strategies alternatives sequentially. The following is an alternative order of priority strategies:

a. Expanding the product sales network through consignment or joint ventures in winning the potential of the bakery business.

The Procake Cake Shop Company is expanding its product sales network by collaborating with other similar companies, such as entrusting its products to outlets that sell the same type of product lines, this effort is carried out to expand the sales market.

b. Maximizing the quality of human resources and production operations by conducting training around company SOPs.

The company conducts training around company SOPs such as sanitation hygiene, establishes working hours and good work shifts to improve the quality of professional employees in production operations.

c. Utilizing technological developments in maximizing marketing to increase sales volume. 
Technological developments can be used as a company as an opportunity to maximize marketing to increase sales volume. Companies can take advantage of current food delivery service trends such as Go-food or grab food.

d. Standardize all lines of the company's organization and renew production equipment to maximize the company's operational quality.

Standardization is carried out in the production operational lines, financial management, HR recruitment, marketing management and all information about company organizations in order to maximize company operations. The company also renewed facilities and technology to support the company's production activities.

e. Adding types of products and services in the face of increasingly intense competition in the bakery industry that continues to increase.

Product innovation is an alternative strategy that can be done by the company in increasing competitiveness, by conducting quality product innovations, the Procake Cake Shop can have an attraction that is able to compete with similar companies.

\section{Conclusions}

The results of research conducted by the author regarding Procake Cake Shop Business Development Strategy, can be drawn several conclusions including:

The results showed that internal factor analysis was found at Procake Cake Shop. First the strength factors that can be the potential and driving force of bakery development are the number of employees owned, product quality in the form of taste, texture, appearance and aroma, affordable product prices, strategic store location, work ability and employee loyalty, segmentation and targets the intended market, the establishment of employee work shifts and a comfortable work environment.

Second, also found the results of the internal factor analysis of the Procake Cake
Shop in the form of weaknesses or weaknesses that must be corrected or minimized by this company, namely employee hospitality and appearance that is less than optimal, inconsistent product packaging, production equipment that is rarely updated, employee facilities that have not been meet the standards, financial management that is not going well, promotion has not been maximized, selection of suppliers that are less selective and procurement of raw materials, sanitation and hygiene do not have standards, irregular operating hours, production locations that are not in accordance with the standards.

The results of the study indicate that an external factor analysis of the Procake Cake Shop was found. First, the opportunity factor that can be utilized by the company to develop is the company fulfilling the licensing and certification of establishing a bakery business, the company has halal certification from MUI and BPOM product certification, the bakery business trend is increasing, the bakery business business opportunity in the technological era.

Second, also found the results of an external factor analysis of the Procake Cake Shop in the form of threats or treats that must be addressed and avoided by this bakery is the number of competitors is increasing every year, business competition of similar businesses is saturated, the rise of artists / celebrities who set up bakery businesses.

An accurate strategy for developing a Procake Shop business is as follows:

a. The results of the IE matrix analysis of the Procake Cake Shop position in cell II are Growth with coordinates of 2.57; 3.18 .

b. An alternative priority strategy based on the results of the QSPM matrix analysis is to expand the product sales network through consignment or joint ventures in winning the potential of the bakery business. 


\section{References}

Andari, R. (2015). RM Development Strategy Bancakan Rice as a Culinary Tourism Attraction in the City of Bandung.

Anonym. 2018. Cake Artis Serbu Bandung. Online: http://www.koran-jakarta. com/cake-artis-serbu-bandung/

Anonym. General Business Knowledge. Online:https://pakaroti.com/businessknowledge/general-business-know ledge / licensing-and-certification

AW Marsum. (2005). Restaurant and all its problems. Yogyakarta: Andi Offset.

C. Michael Hall, Liz Sharples, RM, \& Cambourne, NM and B. (2003). Food Tourism Around the World: Development, management and markets. Tourism Review International. https://doi.org/10.1016/B978-0-75065503-3.50005-1

Carta, M. (2007). Creative City: Dynamics, Innovation, Action. Palermo: List.

David, FR (2004). Strategic Management: Concepts. Translation of Drs. Alexander Sindoro. Jakarta: IND: PT. Index.

Emy Khikmawati, Anggraini, M., \& Ilal, N. (2018). Determination of Business Strategy in Greyoung Bakery Bread Industry Company Through SWOT Analysis Approach. Accounting Research and Management, 7 (1).

Hasibuan, M. (2014). Human Resource Management. Jakarta: PT. Earth Literacy.

Husein Umar. (2010). Marketing and Business Research. Jakarta: Gramedia Main Library.

Kotler, A. (2001). Marketing Principles. Jakarta: Erlangga.

Latif, Fitri Cahya, Ngangi, Charles R., Talumingan, Celsius, Rori, YPI (2015). Nice Bakery Business Marketing Strategy in Tondano. 2 (3).

Moehyi, S. (1992). Food Institution and Food Service Providers. Jakarta: Bharata.
Nefissa, SN (2015). Business Development Strategy. Hidayatullah Islamic State University.

Ningsih, C. (2014). The Synergy of Tourism-Based Creative Industries with the National Industry Development Strategy Towards Globalization. Journal of Resort \& Leisure Research and Development.

Ningsih, c., \& Sudono, A (2016). The competitiveness of Indonesia's tourism industry in the face of the ASEAN Economic Community (AEC). Heritage, Culture and Society, 367-370

Purwati, T. (1994). Catering Management. Yogyakarta: FPTK, Teacher Training and Education Institute.

Rangkuti, F. (2015a). Techniques for Dissecting Business Case SWOT Analysis. Jakarta: PT. Gramedia Main Library.

Rangkuti, F. (2015b). SWOT Analysis Business Case Surgery Techniques. Jakarta: PT. Gramedia Main Library.

Richard Sihite. (2000). Hotel Management. Surabaya: SIC.

Richardson, \& Fluker. (2004). Understanding and Managing Tourism. Australia: Pearson Education.

Robbins, SP, \& Coulter, M. (2010). Management Edition 1. Jakarta: Erlangga.

Solihin, I. (2012b). Strategy Management. Jakarta: Erlangga.

Sulastiyono, A. (2008). Hotel Management Bandung: Alfabeta.

Sulistyaningrum, E. (2015). Analysis of Business Development Strategies in Small and Medium Enterprises (Study on Arando Traditional Cake Business in Medan). Commerce and Business.

Sumarwan, U. (2013). Revealing the Service Quality of 15 Bakery in Jakarta, Bogor, Serpong, Bandung. BAKERY MYSTERY SHOPPING.

Wahyudi. (2017). Statistics on Applied Economics Concepts, Theories and 
Applications. Jakarta: Gramedia Main Library.

Wahyuni, S. (2012). Business Development Strategy at PT. Griya Nutrition Bandung. Indonesian Education University.

Wiwoho, A. (2008). Held Knowledge: Theory \& Practice (Marina A. Sofyan and Yati Sumiharti, Ed.). Jakarta: Erlangga.

Yogaswara, ED (2015). Business

Development Strategy in Gama
Catering in the City of Bandung. Yusnita, HW, \& Yulianto, A. (2013). Restaurant Food \& Beverage Efforts in Improving. IV (1), 67-81. https://doi.org/10.1109/CEIDP.1988. 26361

Zuwita, R. (2012). Benefits of Patiseri Business Learning Outcomes as a Bakery Business Readiness. Indonesian Education University. 